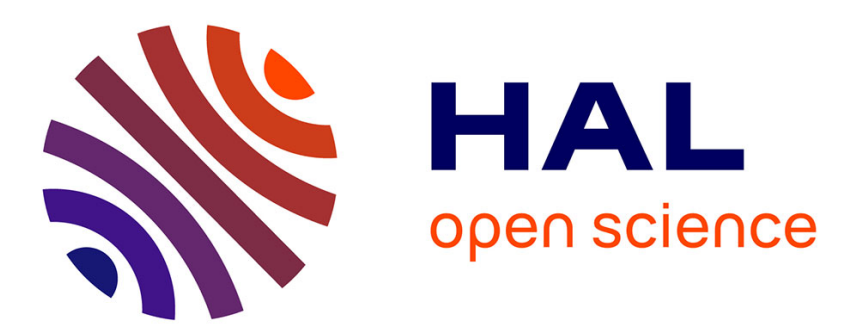

\title{
Task allocation and interactions among females in Euglossa carolina nests (Hymenoptera, Apidae, Euglossini)
}

\author{
Solange Augusto, Carlos Garófalo
}

\section{To cite this version:}

Solange Augusto, Carlos Garófalo. Task allocation and interactions among females in Euglossa carolina nests (Hymenoptera, Apidae, Euglossini). Apidologie, 2011, 42 (2), pp.162-173. 10.1051/apido/2010040 . hal-01003574

\section{HAL Id: hal-01003574 https://hal.science/hal-01003574}

Submitted on 1 Jan 2011

HAL is a multi-disciplinary open access archive for the deposit and dissemination of scientific research documents, whether they are published or not. The documents may come from teaching and research institutions in France or abroad, or from public or private research centers.
L'archive ouverte pluridisciplinaire $\mathbf{H A L}$, est destinée au dépôt et à la diffusion de documents scientifiques de niveau recherche, publiés ou non, émanant des établissements d'enseignement et de recherche français ou étrangers, des laboratoires publics ou privés. 


\title{
Task allocation and interactions among females in Euglossa carolina nests (Hymenoptera, Apidae, Euglossini)*
}

\author{
Solange Cristina Augusto ${ }^{1}$, Carlos Alberto GaRófalo ${ }^{2}$ \\ ${ }^{1}$ Instituto de Biologia, Universidade Federal de Uberlândia, 38400-902, Uberlândia, MG, Brazil \\ ${ }^{2}$ Departamento de Biologia, Faculdade de Filosofia, Ciências e Letras de Ribeirão Preto, USP, 14040-901, \\ Ribeirão Preto, SP, Brazil
}

Received 17 November 2009 - Revised and accepted 2 March 2010

\begin{abstract}
Multifemale nests of Euglossa carolina were studied to investigate task allocation during nest reactivations according to both the females' size and order of emergence. The study was carried out at the campus of the University of São Paulo, Ribeirão Preto, Brazil, from January, 1990 to March, 1992. The activities of the females were recorded during the reactivation processes in eight nests maintained in observation boxes. The size of each female was determined by measuring the forewing length and the maximum width of the head. Nest reactivations were performed by one or more females in the presence or absence of a female that had participated in a previous reactivation process. Usually, the first emerging females remained in the nests and established associations in which the oldest became dominant. All nestmates had mated, and developed ovaries and did not differ in size. Task allocation was recognized by behavioral characteristics, namely, agonism and oophagy in cells oviposited by other females.
\end{abstract}

Euglossa / reproductive skew / oophagy / social structure / task allocation

\section{INTRODUCTION}

Solitary foundation, nesting in preexisting cavities, nest reactivation by successive generations and multifemale nests are characteristics shared by most species of Euglossini with known nest (Zucchi et al., 1969a, b; Garófalo, 1985, 1992; Augusto and Garófalo, 2004, 2009). Euglossa, with 122 described species (Nemésio, 2009), is the only genus of euglossines that presents species with multifemale nests, task allocation and overlapping generations (Garófalo, 1985; Ramírez-Arriaga et al., 1996; Augusto and Garófalo, 2004, 2009; Cocom Pech et al., 2008) as well as solitary and communal species (Dressler, 1982; Young, 1985; Roberts and Dodson, 1967;

Corresponding author: S.C. Augusto, scaugusto@umuarama.ufu.br

* Manuscript editor: Stan Schneider
Garófalo et. al., 1998; Soucy et al., 2003; Otero et al., 2008).

Euglossa carolina, which has been erroneously treated as Euglossa cordata, is a species widely distributed in the Atlantic Forest, from Paraiba to Rio Grande do Sul, and very common in some areas, especially in semideciduous forests, typical of interior areas of eastern Brazil (Nemésio, 2009).

Nests of E. carolina are founded by a single female that constructs, provisions and oviposits in 6-10 cells, and afterwards spends most of her time at the nest entrance. When her daughters emerge, some of them remain in the natal nest and begin to reactivate it, provisioning and ovipositing in new or old cells (Garófalo, 1985, 1992). Observations of the intranidal behavior of females of E. carolina during nest reactivation have demonstrated that one of them becomes clearly dominant over the others, the mother in matrifilial associations, and one sister in 
sororal associations (Garófalo, 1985). The dominance behavior is characterized by two components: reproductive, with the dominant female replacing subordinate's eggs (daughters or younger sisters) with her own, and behavioral, with the dominant exhibiting agonistic behavior towards subordinate. In addition to dominance behavior, the dominant female rarely leaves the nest and becomes the major guard bee, while the subordinate females assume the tasks of collecting resin, constructing or reusing cells, and provisioning and ovipositing in them (Garófalo, 1985). Similar social organization has been reported by Ramírez-Arriaga et al. (1996) for Euglossa atroveneta, Augusto and Garófalo (2009) for Euglossa fimbriata and Cocom Pech et al. (2008) for Euglossa viridissima.

In multifemale colonies of $E$. towsendi, all females also are reproductively active. However, since behavioral interactions of dominance and subordination are lacking in this species, the females were classified as either egg-laying or as forager/egg-laying. In this species reproductive dominance is displayed by an egg-laying female that, after oophagy, replaces the forager/egg layer's eggs with her own. When more than one egg-laying female participates in a reactivation, multiple egg replacements in the same cell may occur (Augusto and Garófalo, 2004).

In matrifilial or sororal associations of $E$. carolina, it has been observed that the oldest female assumes nest dominance (Garófalo, 1985). Age and order of eclosion have been reported as determinant factors for task allocation in some species of primitively eusocial bees and wasps (Kumar, 1975; Eickwort, 1986; Yanega, 1989; Schwarz and O'Keefe, 1991; Schwarz and Woods, 1994; Tsuji and Tsuji, 2005), as in some Euglossa species. There are indications, moreover, that body size also influences the tasks assumed by females in social nests (Plateaux-Quénu, 1992; Wcislo, 1997; Hogendoorn and Velthuis, 1999; Smith et al., 2008).

As in colonies of other primitively social bees, task allocation and, consequently, the degree of reproductive sharing among members in Euglossa colonies can be analyzed in terms of reproductive skew models, either transac- tional or tug-of-war. The transactional models predicts that dominants (concession model) or subordinates (restraint model) can maintain full control over the allocation of reproduction in multifemale nests, while in tug-of-war model, reproduction can be shared by members of the group (Johnstone, 2000; Reeve and Keller, 1995, 2001; Langer et al., 2004, 2006).

To better understand the factors involved in E. carolina multifemale nest task allocation, this study investigated which females assumed dominant and subordinate functions during nest reactivation both in the presence and in the absence of females that had participated in the previous reactivation, taking into consideration their order of emergence and size. Furthermore, details of dominant female behavior for the maintenance of reproductive dominance over subordinates, nest productivity, and a discussion on task allocation according to models of reproductive skew are presented.

\section{MATERIAL AND METHODS}

The study was carried out on the campus of the University of São Paulo, Ribeirão Preto (between $21^{\circ} 05^{\prime}-21^{\circ} 15^{\prime} \mathrm{S}$ and $47^{\circ} 50^{\prime}-47^{\circ} 55^{\prime} \mathrm{W}$ ), State of São Paulo, Brazil, from January, 1990 to March, 1992. Eight nests $\left(\mathrm{N}_{1}\right.$ to $\left.\mathrm{N}_{8}\right)$ of E. carolina maintained in wooden boxes (inside dimensions $11.0 \times 11.0 \times 5.0 \mathrm{~cm}$ or $8.2 \times 8.2 \times 3.7 \mathrm{~cm}$ or $7.0 \times 16.0 \times 5.0 \mathrm{~cm}$ ) in the Ecology laboratory were studied. The wooden boxes were covered with a glass lid and had a $10-\mathrm{mm}$ circular entrance hole on one side. The bees were allowed free access to the outdoors via plastic piping that ran from the boxes through holes in the laboratory wall.

Four nests $\left(\mathrm{N}_{1}\right.$ to $\left.\mathrm{N}_{4}\right)$ were set up with cell clusters (ranging from four to 13 cells) removed from other nests that were being maintained in the laboratory. Three other nests $\left(\mathrm{N}_{6}\right.$ to $\left.\mathrm{N}_{8}\right)$, having had all females removed, consisted of only cells with immature individuals (ranging 13 to 17 cells). Finally, one nest $\left(\mathrm{N}_{5}\right)$, which was obtained from trap-nests placed at an orchard in Santa Rita do Passa Quatro - SP, Brazil, according to the method of Garófalo et al. (1993), had its foundress female removed and its five brood cells transferred to an observation box. 


\subsection{Nest development}

Direct observations of intranidal activities were usually made from 7 a.m. to 6 p.m. through the glass lid covering each wooden box and were recorded in periods ranging from $30 \mathrm{~min}$ to $6 \mathrm{~h}$ for a total of $1080 \mathrm{~h}$. To verify the occurrence of oophagy and egg replacement, multifemale nests were observed up to $6 \mathrm{~h}$ after a female finished the provisioning of her cell and ovipositing in it. In addition to recorded cases, other cases of oophagy and egg replacement must have occurred when the nests were not being observed. When more than two females shared a nest, they were marked with spots of color on their scutum to facilitate the identification of each individual.

The interactions between dominant $(=\mathrm{DF})$ and subordinate $(=\mathrm{SF})$ females during the provisioning of 42 cells, construction of the cell collar, oviposition and operculation of 38 cells by SF, were recorded over four reactivation processes. According to Augusto and Garófalo (2004), a reactivation process $(=\mathrm{R})$ is initiated when one newly emerged female remains in its natal nest and begins to work in it. The behaviors performed by E. carolina SF during the reactivations were similar to those of $E$. fimbriata SF (see Augusto and Garófalo, 2009).

While the SF performed their tasks, the following variables were recorded: (i) if the DF was present in the nest; (ii) when present, if she displayed agonistic behavior; and (iii) the number of agonistic acts by DF against SF.

Interactions during activities such as the discharging of resin loads, the construction of new cells or the preparation of an old cell for re-use were not recorded because the first activity occurs infrequently and the others usually occur at night when the nests were not being observed.

\subsection{Size and ovarian development of females}

To determine the size of females $\left(\mathrm{n}_{\mathrm{DF}}=17\right.$ and $\mathrm{n}_{\mathrm{SF}}=32$ ), they were collected from their nests and placed in individual glass vials. They were then transferred to a refrigerator maintained at $6{ }^{\circ} \mathrm{C}$ until their movements were reduced. After that, the length of the right forewing from the proximal portion of cell $\mathrm{M}$ to the distal end of the marginal cell, and the maximum width of the head were determined using an ocular micrometer under a stereomicroscope. Afterward, the bees were returned to their nests.
In order to determine whether or not the females sharing a nest were inseminated and showed developed ovaries, four DF and 11 SF were removed from their nests after having been behaviorally identified and were dissected. Each spermatheca was crushed between a slide and a cover slip, and examined under a microscope.

\subsection{Statistical analyses}

Pearson correlation analyses were performed to verify the intensity of association between: (i) the number of brood cells produced by SF and the time of residence in the nest; (ii) the number of brood cells produced by SF and their activity period; (iii) the number of subordinates and nest productivity; (iv) the total number of females and per capita brood production; and (vi) the number of agonistic interactions and duration of cell collar construction. The Kruskal-Wallis test was used to compare the number of cells produced by SF according to the number of SF present in each reactivation processes. Student's t-test and the Mann-Whitney test were used to assess possible size differences among females and differences in time of residence between dominants and subordinates. Finally, the paired t-test was used for size comparison between females of each association (DF and SF).

These analyses were performed using the statistical package Systat for Windows, version 10.2, Software Inc., 2002.

\section{RESULTS}

\subsection{Nest development}

Twenty-one reactivation processes were observed during the study. Of the 96 females observed emerging, $54(56.2 \%)$ remained in the nests and participated in reactivation processes (= reactivating female) ovipositing in at least one cell (Tab. I). These females began collecting resin or larval food when they were twothree days old.

Of the 42 other females (43.8\%), 21 did not return to the nest after their first flight and 21 disappeared from nests before starting any activity $(\mathrm{n}=12)$, or after performing some activity such as the provisioning of the first cell $(n=6)$, collecting some resin $(n=2)$ or cell 
Table I. Reactivation processes observed in Euglossa carolina nests, number of brood cells produced, emergence and number of reactivating/non-reactivating females.

\begin{tabular}{ccccccc}
\hline \multirow{2}{*}{ Nest } & $\begin{array}{c}\text { Total of } \\
\text { reactivation } \\
\text { processes }\end{array}$ & $\begin{array}{c}\text { Total of } \\
\text { brood cells }\end{array}$ & \multicolumn{2}{c}{ Emergence** } & \multicolumn{2}{c}{ Number of females (\%): } \\
\cline { 5 - 7 } & & & O & O $^{*}$ & Reactivating & Non-reactivating \\
\hline N1 & 3 & 25 & 15 & 3 & $7(46.6)$ & $8(53.4)$ \\
N2 & 2 & 13 & 10 & 0 & $7(70.0)$ & $3(30.0)$ \\
N3 & 3 & $33^{*}$ & 13 & 3 & $8(61.5)$ & $5(38.5)$ \\
N4 & 4 & $20^{*}$ & 9 & 0 & $4(44.4)$ & $5(55.6)$ \\
N5 & 3 & 18 & 7 & 3 & $6(85.7)$ & $1(14.3)$ \\
N6 & 2 & 27 & 16 & 5 & $7(43.7)$ & $10(56.3)$ \\
N7 & 1 & 13 & 6 & 6 & $3(50.0)$ & $3(50.0)$ \\
N8 & 3 & 41 & 20 & 9 & $12(60.0)$ & $8(40.0)$ \\
Total & 21 & 190 & 96 & 29 & $54(56.2)$ & $42(43.8)$ \\
\hline
\end{tabular}

* Two individuals did not emerge.

** Some individuals emerged in periods when the nests were not being observed and did not return to nests after flying by the first time.

construction $(n=1)$; all these females were denominated non-reactivating females.

The duration of reactivation (from the beginning of the female's activities until her last oviposition) ranged from 8 to 125 days $(\mathrm{x}=54.0 \pm 32.0 ; \mathrm{n}=21)$. After finishing a reactivation, some females remained in the nest without performing reproductive activities (=inactivity period of nest), while one of them frequently participated in the subsequent reactivation.

\subsection{Reactivation processes}

\subsubsection{Females participating in the reactivation processes and task allocation}

The number of females participating in a reactivation process ranged from 1 to 5 . However, the number of females working together on the same reactivation process was three, one of them behaving as dominant and the others as subordinate.

In most reactivations, a tendency was observed for the first, second and third females that returned after their first flight to remain in the nests (Fig. 1). In all reactivation processes occurring in the absence of females that had participated in the previous reactivation (Pattern A) $(n=11)$ (Fig. 1), the first female that remained in the nest behaved as DF $(n=9)$ and the others as SF. In two cases, the reactivations were carried out by a sole female; these were denominated as foraging egg-laying female (FELF).

Eight reactivation processes began in the presence of one female that had participated in the previous reactivation (Pattern B) (Fig. 1). These females stayed in the nest after having behaved as DF $(n=4)$ or SF $(n=4)$ in the previous reactivation processes and all of them assumed the dominant function after the emergence of new reactivating females in the subsequent reactivation.

Associations among unrelated females occurred during two reactivation processes. In the $\mathrm{N}_{1} / \mathrm{R}_{2}$-Pattern A (Fig. 1), according to emergence order, $\mathrm{F}_{4}$ behaved as DF and $\mathrm{F}_{5}$ behaved as SF. Sixteen days after the SF disappeared from the nest, a female of unknown origin (FUO) joined the nest and was accepted by the DF. The FUO behaved as a SF for 38 days, provisioning and ovipositing six cells. She stayed in the nest until next reactivation process $\left(\mathrm{N}_{1} / \mathrm{R}_{3}\right.$-Pattern $\left.\mathrm{B}\right)$, when she became the DF. 
Total number of emerging females

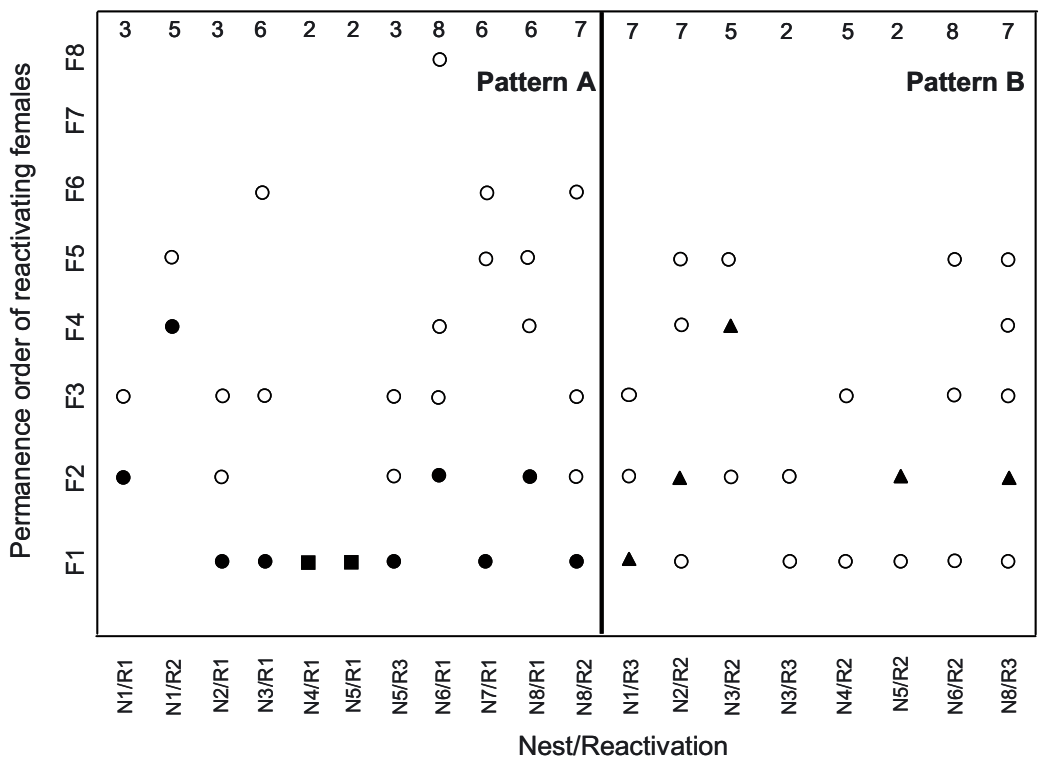

Figure 1. Reactivating females of Euglossa carolina according to permanence order and function assumed in the Patterns A (absence of a prior female) and B (presence of a prior female) reactivations. • Dominant females; $\boldsymbol{\Delta}$ replacement females; o subordinate females and $\boldsymbol{\|}$ foraging/egg-laying females (in reactivation processes that had only one female). Note: all pattern B reactivations began in the presence of a female that became dominant, and in five of them she was replaced by the oldest subordinate present in the nest (replacement females).

\subsubsection{Replacement of dominant female}

During five reactivation processes $\left(\mathrm{N}_{1} / \mathrm{R}_{3}\right.$, $\mathrm{N}_{2} / \mathrm{R}_{2}, \mathrm{~N}_{3} / \mathrm{R}_{2}, \mathrm{~N}_{5} / \mathrm{R}_{2}$ and $\mathrm{N}_{8} / \mathrm{R}_{3}$-Pattern B) (Fig. 1), 23.8\% of the observed total, the DF disappeared from the nest and was replaced by a SF. The substitute DF was always the oldest $\mathrm{SF}$ that had stayed in the nest (in the $\mathrm{N}_{2} / \mathrm{R}_{2}$, $\mathrm{N}_{3} / \mathrm{R}_{2}$ and $\mathrm{N}_{8} / \mathrm{R}_{3}$, the $\mathrm{F}_{1}, \mathrm{~F}_{2}$ and $\mathrm{F}_{1}$, respectively, abandoned the nest before the dominant female disappeared), except in one case $\left(\mathrm{N}_{5} / \mathrm{R}_{2}\right.$-Pattern B) where two SF emerged on the same day and the younger $\left(\mathrm{F}_{2}\right)$ assumed the dominant function (Fig. 1).

\subsubsection{Size of females}

The maximum head width (HW) and forewing length $(\mathrm{FWL})$ of $\mathrm{DF}(\mathrm{n}=17)$ ranged from 4.1 to $4.6 \mathrm{~mm}(\mathrm{x}=4.3 \mathrm{~mm} \pm 0.18)$ and 3.8 to $4.3 \mathrm{~mm}(\mathrm{x}=4.01 \mathrm{~mm} \pm 0.20)$, respectively, and ranged for SF $(n=37)$ from
3.8 to $4.7 \mathrm{~mm}(\mathrm{x}=4.25 \mathrm{~mm} \pm 0.19)$ and 3.4 to $3.8 \mathrm{~mm}(\mathrm{x}=3.91 \mathrm{~mm} \pm 0.19)$, respectively. DF measurements were not significantly greater than those of SF (WH: t-test, $Z=-1.80 ; P>0.286$; FWL: Mann-Whitney test, $Z=-1.700 ; P>0.089)$. Similar results were obtained with the paired t-test regarding the size of females (DF and SF) working at the same reactivation $(\mathrm{WH}, \mathrm{t}=0.29: P>0.05$; FWL, $\mathrm{t}=0.36 ; P>0.05)$.

\subsection{Nest productivity}

The number of cells oviposited by SF ranged from one to $10(\mathrm{x}=4.0 \pm 2.9$ cells; $\mathrm{n}=24$ ) and was significantly correlated with the time of residence $(\mathrm{r}=0.649 ; P<0.05 ; \mathrm{n}=$ $24)$ and period of activity $(\mathrm{r}=0.683 ; P<0.05)$ (Fig. 2), both ranging from 5 to 62 days (time of residence: $\mathrm{x}=24.8 \pm 15.7$ days; period of activity: $\mathrm{x}=20.6 \pm 14.0$ days; $\mathrm{n}=24$ ). 


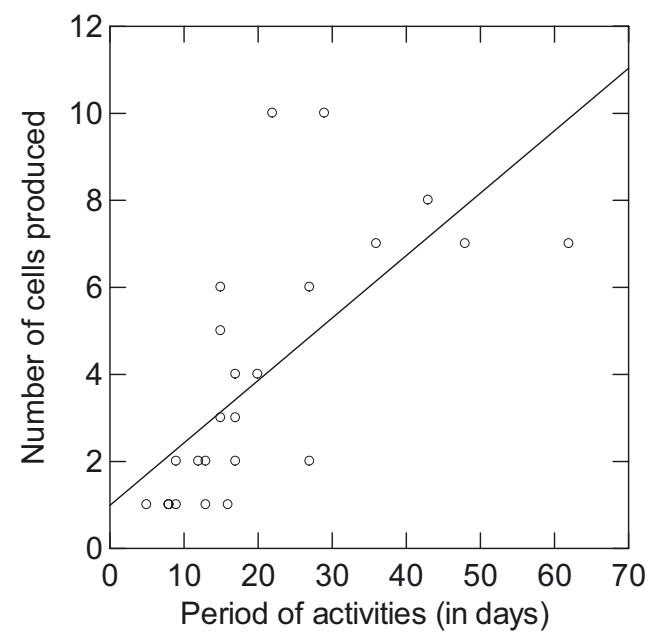

A

Figure 2. Number of cells produced by subordinate females of Euglossa carolina, according to period of activity $(\mathrm{r}=0.683 ; P<0.05)$.

After interrupting their reproductive activities, some SF stayed in the nest for periods that ranged from two to 23 days. The residence time of the DF ranged from 45 to 146 days $(\mathrm{x}=80.1 \pm 30.6$ days; $\mathrm{n}=10)$ and was significantly higher than the residence time of SF (U $=8.00 ; P<0.05)$.

Nest productivity (total of brood cells produced during a reactivation process) was significantly correlated with the number of SF working in the reactivation $(\mathrm{r}=0.673 ; P<$ $0.05 ; \mathrm{n}=14)$ (Fig. 3A), although the number of cells oviposited per female was not significantly different, regardless of the number of $\mathrm{SF}$ in each reactivation (Kruskal-Wallis test, $3.461, P>0.05)$. On the other hand, the percapita brood production was negatively correlated with the total of females $(\mathrm{FD}+\mathrm{SF})(\mathrm{r}=$ $-0.637 ; P<0.005 ; \mathrm{n}=14$ ) (Fig. 3B).

All dissected females (DF: $n=4$; SF: $n=$ 11) had developed ovaries and had been inseminated.

\subsection{Interactions among females}

Two general types of agonistic behaviors were distinguished: approaching, in which the DF walks towards the SF and stops close to her
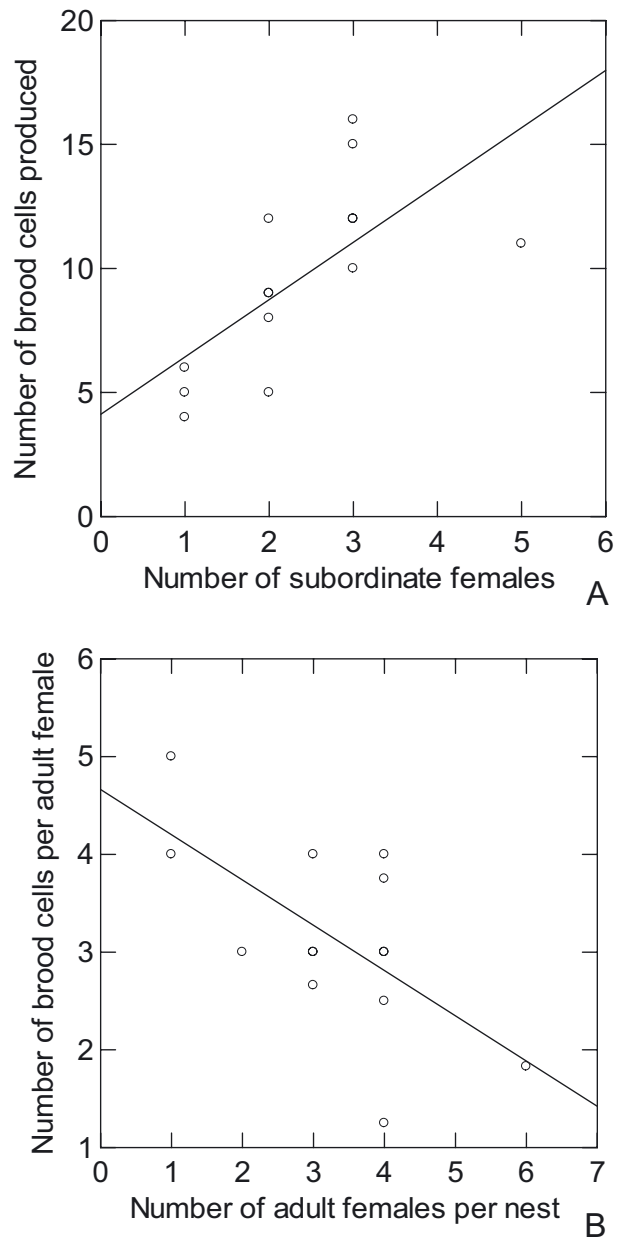

Figure 3. Relationship between the number of subordinate females and the total number of brood cells produced during the reactivation processes in $\mathrm{Eu}$ glossa carolina nests $(\mathrm{r}=0.673 ; P<0.05 ; \mathrm{n}=$ 14) (A) and between number total of adult females participating in a reactivation process and number of brood cells (per-capita brood production) $(\mathrm{r}=-$ 0.637; $P<0.05 ; \mathrm{n}=14)(\mathrm{B})$.

(Fig. 4A), resulting in the interruption of the SF activity, and attacking, when the DF makes a sudden movement towards the SF and attacks her (Fig. 4B). During the attacks, the following types of behavior were recorded: (a) the DF touched the SF in varying regions of body with her head or (b) she used her mandibles to bite the legs or the abdominal tip of SF. When the 


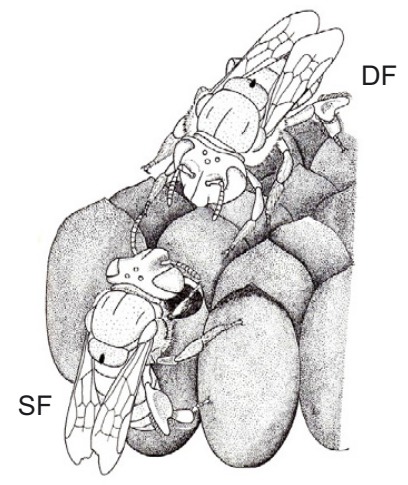

A

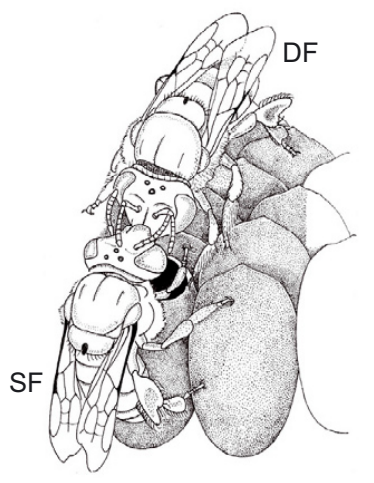

B

Figure 4. Agonistic behaviors performed by dominant females (DF) in relation to subordinate females (SF) of Euglossa carolina. The DF interrupted the activities of SF by first approaching threateningly (A), and then attacking by pushing the SF away with her head (B). Note the difference in wing wear between dominant and subordinate females. Drawings: José M. Macário Rêbelo.

DF displayed these behaviors, the SF retreated from the place where she was working. Only rarely did a SF react to the agonism of a DF. In some cases, the SF stopped what she was doing, leaned to one side and raised her legs towards the DF. She continued waving her legs until the DF retreated and then she resumed her activities.

The percentage of provisioning (53.0\%) and collar construction $(97.0 \%)$ processes in which interactions among dominant and subordinate were observed was higher than the percentage observed in operculation (Phase I and II) $(37.0 \%)$ (Fig. 5).
Both types of agonistic interactions, approaching and attacking, were more frequently observed during these processes (Fig. 5). During SF ovipositions, no DF agonistic behaviors were observed. It was observed that attacking was more frequent than approaching in Pattern $\mathrm{B}$ reactivations (Fig. 6).

In six operculation processes observed during Pattern $\mathrm{B}$ reactivations, the SF was removed from the cell by an attacking DF, who finished the operculation. All attempts made by SF to return to the cell were unsuccessful, after which she usually began to work in another cell.

Besides agonistic behavior, the DF performed oophagy in SF-oviposited cells. After opening the cell, inserting her head and performing oophagy, the DF oviposited. Upon finishing her oviposition, the DF immediately began the operculation process following the same behavioral sequence of the SF. The interval between SF cell operculation and DF oophagy ranged from $5 \mathrm{~min}$ to $23.3 \mathrm{~h}(\mathrm{n}=$ 18); most oophagy occurred on the same day of oviposition by the SF $(n=16)$ and in thirteen cases the interval was less than $60 \mathrm{~min}$.

\section{DISCUSSION}

In reactivations observed in E. carolina nests, whether in the absence or presence of a female participating in the previous processes, it was confirmed that the first females to emerge tended to remain in the nest and establish small associations with two or three other females, who then acted together. In reactivation processes that occurred in the absence of females that had participated in the previous reactivation (Pattern A), when an association was established, the first female to remain in the nest became its "owner" and assumed the dominant function, while the others took on the subordinate role. In Pattern B reactivations, new females that remained in the nest became subordinates to a female that participated in the previous reactivation. In spite of the variation of size observed among females, no significant physical differences were found between the two categories. This result 


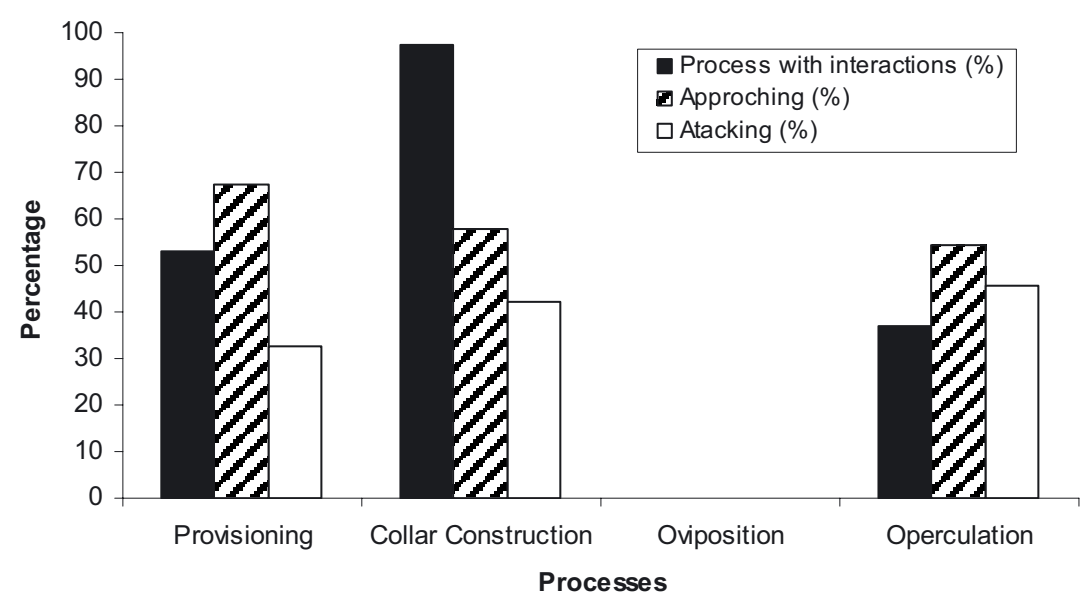

Figure 5. Percentage of provisioning, collar construction, oviposition and operculation processes performed by subordinate females of Euglossa carolina, in which interactions with the dominant female occurred, and percentage of approaching and attacking that occurred during these processes.
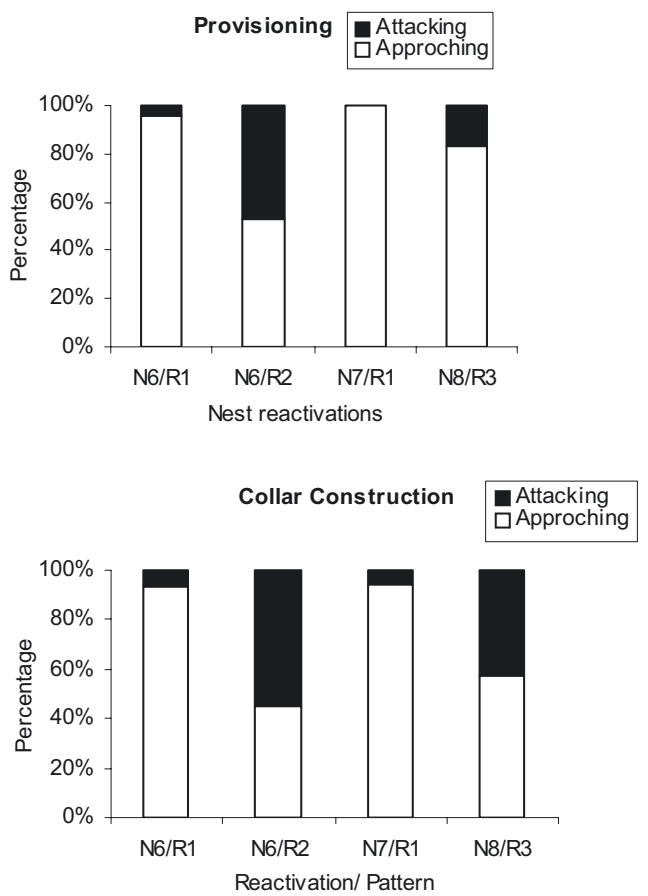

Figure 6. Percentage of agonistic behaviors, approaching and attacking interactions, displayed by the dominant female during the activities of provisioning and collar construction performed by subordinate females of Euglossa carolina, according to reactivation patterns $A\left(N_{6} / R_{1}\right.$ and $\left.N_{7} / R_{1}\right)$ and $B$ $\left(\mathrm{N}_{6} / \mathrm{R}_{2}\right.$ and $\left.\mathrm{N}_{8} / \mathrm{R}_{3}\right)$. confirmed the hypothesis that age instead of size is the major proximate factor determining task allocation. Additionally, the replacement of the DF by the oldest subordinate female reinforces the idea of an age-based dominance hierarchy, as occurs in other primitively eusocial bee species (Michener et al., 1971; Kumar, 1975; Eickwort, 1986; Yanega, 1989; Schwarz and O'Keefe, 1991; Schwarz and Woods, 1994; Anerson and Wcislo, 2003; Augusto and Garófalo, 2009).

The positive and significant correlation between number of cells oviposited and number of SF working in each reactivation process, as observed in the present study of $E$. carolina, was also reported by Augusto and Garófalo (2004, 2009) for E. townsendi and E. fimbriata. Moreover, the productivity per SF of E. carolina was similar to that observed in E. townsendi FELF (Augusto and Garófalo, 2004), remaining constant irrespective of the number participating in the reactivation processes. These results characterize communal colonies in which the females demonstrate independence in reproductive activities (Santos and Garófalo, 1994; Kukuk et al., 1998; Soucy et al., 2003; Augusto and Garófalo 2004, 2009). However, productivity per capita was inversely correlated with the total number of 
females $(\mathrm{DF}+\mathrm{SF})$, due to the presence of a DF that does not contribute to cell production.

Because all nest-mates have developed ovaries, have mated and do not differ in size, dominant and subordinate females are recognized by their behavioral characteristics. DF exhibited agonistic behaviors towards SF and the intensities of these behaviors (considering the type attacking) were highest in Pattern B reactivations where the DF had already participated in a reactivation process. These observations suggest that age plays an important role in the behavioral differences displayed by dominants, with the oldest ones becoming more aggressive towards SF. The agonistic interactions observed in E. carolina have been likened to the behavior of some groups of halictine bees (see Arneson and Wcislo, 2003), in which all females are totipotent, as are the females of Euglossa, and the differentiation of dominance-subordination relationships is based on behavioral interactions among adults.

Although the agonistic behaviors displayed by DF do not prevent oviposition by SF, as observed during this study, reproductive dominance, reflected in the monopolization of offspring production, is achieved by the DF through the replacement of SF eggs with her own. Furthermore, by eating SF eggs, the DF gains high-quality nutrients (see Kukuk, 1992) which increase her longevity, as demonstrated by her prolonged residence in the nest, and improve her fecundity, since she replaces all eggs laid by SF and is able to participate in more than one reactivation process.

The monopolization of offspring production leads to the highest reproductive skew, as predicted by the concession-based transactional skew model (Reeve and Keller, 1995, 2001), such as that proposed for E. fimbriata (Augusto and Garófalo, 2009). Moreover, permitting oviposition by SF and afterwards performing oophagy would be a prudent selfish strategy by DF to avoid group dispersal or lethal fighting among females for nest dominance, and is an another prediction of transactional models of reproductive skew (Reeve and Keller, 1995, 2001). Additionally, some subordinates attain an indirect genetic gain by replacing the DF when she dies or disappears from the nest, as occurred in $23.8 \%$ of reactivation processes observed in E. carolina nests.

The behaviors displayed by DF fit the parental parasitism hypothesis (Charnov, 1978; Stubblefield and Charnov, 1986) as an alternative pathway by which insect sociality could have arisen, as discussed by Augusto and Garófalo $(2004,2009)$ for E. townsendi and E. fimbriata, respectively. According to this hypothesis, one female would be under strong selection to parasitize her nestmates if she had the opportunity to do so, as occurs during nest reactivation of Euglossa species. We suggest that this hypothesis better explains the social structure of Euglossa species studied until now than other classical theoretical models that have attempted to explain the origin of insect eusociality.

If the DF of E. carolina replaces all eggs laid by subordinates and mates with only one male, as suggested by Zimmerman et al. (2009) about Euglossa species, a high genetic relatedness between dominant and subordinate females must occur; this favors an optimum reproductive skew, as also predicted by the concession-based transactional skew model (Langer et al., 2004). This condition could help maintain social cohesion in multifemale nests and lead to long-lived colonies through successive reactivation, as reported by Garófalo (1987).

Despite the importance of high degrees of genetic relatedness among cohabiting females in a social behavior context, association among unrelated females was also observed in the E. carolina of this study as well as in $E$. townsendi (Augusto and Garófalo, 2004) and in Euglossa viridissima (Zimmerman et al., 2009), although in very low frequencies. In E. carolina, the acceptance of an unrelated female into the nest could have been due to a lack of SF, whereas in E. townsendi, the absence of within-group aggression may have facilitated the permanence of such females in the nest. As emphasized by Zimmerman et al. (2009), detailed behavioral observations together with the genetic analysis of produced brood can help clarify the relationships among all females of an association and the real contribution of each one to the social context of the nest. 
The dominance-through-oophagy model displayed by E. carolina is similar to that of E. fimbriata (Augusto and Garófalo, 2009) and matrifilial associations of E. viridissima (Cocom Pech et al., 2008). However, in contrast to that of E. viridissima, the oophagy of a mother's eggs by her daughter was observed in neither E. carolina nor in E. fimbrita.

Oophagy followed by oviposition as mechanism of reproductive dominance by a female in E. carolina could explain the small associations established during the reactivation processes, a condition also observed in other Euglossa species that present task allocation (Augusto and Garófalo, 2004, 2009; Cocom Pech et al., 2008). With four ovarioles per ovary, an ovariole length similar to that of solitary bees who produce few mature oocytes in a short time (Martins and Serrão, 2004), Euglossa egg production is limited by morphological constraints and results in relatively low oviposition rates. Thus, in associations formed by a large number of SF, the DF would be prevented from replacing all eggs laid by SF due to her slow rate of egg production, and thereby not be able to maintain her reproductive dominance.

The information available about the intranidal behaviors of females in Euglossa colonies (Garófalo, 1985; Ramírez-Arriaga et al., 1996; Augusto and Garófalo, 2004; Coocom Pech at al., 2008; Augusto and Garófalo, 2009) as well as data obtained from the analyzed content of collected nests (Dodson, 1966; Sakagami et al., 1967; Roberts and Dodson, 1967; Zucchi et al., 1969a; Eberhard, 1988) suggest that social nesting in this genus is probably more frequent than solitary life. Besides communal nests, two types of social structure have been observed so far in Euglossa species: colonies with dominant and suborinate females, in which dominance is maintained by oophagy and agonistic behavior, as observed in E. fimbriata (Augusto and Garófalo, 2009) and E. carolina, and colonies of species such as E. townsendi, in which dominance and agonistic behavior by a single female do not occur and, despite some oophagy, no apparent hierarchical dominance occurs.

Oophagy is probably associated with agonistic interactions, both of which are displayed by E. carolina and E. fmbriata (Augusto and Garófalo, 2009) in order to maintain the dominance of a sole female, and are probably precursors to queen behavior in highly social bees.

\section{ACKNOWLEDGEMENTS}

This research was supported by the Conselho Nacional de Desenvolvimento Científico e Tecnológico $(\mathrm{CNPq})$. We are grateful to José Carlos Serrano for technical help and José M. Macário Rêbelo for the drawings. The manuscript was improved by a number of helpful remarks from two anonymous referees. Solange C. Augusto received a grant from the Coordenadoria de Aperfeiçoamento de Pessoal de Nível Superior (CAPES).

Répartition des tâches et interactions entre femelles dans les nids de Euglossa carolina (Hymenoptera, Apidae, Euglossini).

Euglossa / oophagie / organisation sociale / répartition des tâches/ biais reproductif

\section{Zusammenfassung - Aufgabenverteilung und} Interaktionen zwischen Weibchen in Euglossa carolina Nestern (Hymenoptera, Apidae, Euglossini). Detailbeobachtungen über das Verhalten von Euglossa carolina Weibchen im Nest zeigten, dass es in Nestern mit mehreren Weibchen zu einer Dominanz durch die Mutter oder eine der Schwestern kommt. Um die Aufgabenverteilung in E. carolina Nestern mit mehreren Weibchen besser verstehen zu können, untersuchten wir, welche der Weibchen während der Nestreaktivierung dominante oder untergeordnete Funktionen übernehmen. Hierzu beobachteten wir die Folge, in der die Weibchen schlüpften, ihre Größe, sowie Verhaltensmerkmale. Außerdem präsentieren wir Daten zur Nestproduktivität und diskutieren die Aufgabenverteilung vor dem Hintergrund von Modellen zur Verteilung des Reproduktionsvermögens (reproductive skew). Die Untersuchung wurde auf dem Campus der Universität São Paulo, Ribeirão Preto, im Staat São Paulo, Brasilien, zwischen Januar 1990 und März, 1992 durchgeführt. Acht E. carolina Nester $\left(\mathrm{N}_{1}\right.$ bis $\left.\mathrm{N}_{8}\right)$ wurden in Holzkästchen gehalten. Die Aktivitäten wurden über einen Gesamtzeitraum von 1080 Stunden registriert. Die Interaktionen zwischen dominanten (DF) und untergeordneten Weibchen (SF), insbesondere bezüglich Verproviantierung der Brutzellen, Bau des Zellkragens, Eiablage und Zellverdeckelung durch SF-Weibchen, wurden über vier Reaktivierungsphasen beobachtet. Als Größenmerkmale der Weibchen wurde die 
Länge des Vorderflügels vom proximalen Punkt der M-Zelle bis zum distalen Ende der Marginalzelle, sowie die maximale Kopfbreite bestimmt. Vier DF- und 11 SF-Weibchen wurden aus den Nestern entfernt und seziert, um die Ovarentwicklung und eventuelle Verpaarung festzustellen. Insgesamt wurden 21 Reaktivierungsprozesse beobachtet.

Von den 96 Weibchen, deren Schlupf registriert wurde, verblieben 54 (56,2\%) im Nest und waren an Reaktivierungsprozessen beteiligt (Tab. I). Die Zahl der Weibchen pro Reaktivierungsprozess lag zwischen 1 und 5. Die Zahl der Weibchen, die bei jeweils einer Reaktivierung zusammenarbeiteten betrug 3. Außerdem registrierten wir den Anteil der erstgeschlüpften Weibchen, die nach dem ersten Flug zum Nest zurückkehrten (Abb. 1). Reaktivierungen erfolgten durch eines der mehrere Weibchen, sowohl in der Gegenwart als auch in Abwesenheit von Weibchen, die bereits an einer früheren Reaktivierung beteiligt waren. In Nestern mit mehreren Weibchen war meist das älteste dominant und die anderen untergeordnet, wobei alle Weibchen entwickelte Ovarien hatten, verpaart waren und keine Größenunterschiede zeigten. Das DF-Weibchen wurde in $23,8 \%$ aller untersuchten vollständigen Reaktivierungsprozesse $(n=21)$ ersetzt. Die Nestproduktivität war signifikant mit der Zahl an SFWeibchen korreliert, die am Reaktivierungsprozess beteiligt waren $(\mathrm{r}=0,673 ; P<0,05 ; \mathrm{n}=14)(\mathrm{Abb}$. 3A). Die Zahl an SF-Weibchen hatte aber keinen signifikanten Einfluss auf die Zahl der Zellen, in die Eier abgelegt worden waren (Kruskal-Wallis Test, $3,461, P>0,05)$. Die Brutproduktion per capita war negativ mit der Gesamtzahl an Weibchen korreliert $(\mathrm{DF}+\mathrm{SF})(\mathrm{r}=-0,637 ; P<0,005 ; \mathrm{n}=14)$ (Abb. 3B).

Wir konnten zwei generelle Typen agonistischer Interaktionen unterscheiden, Annäherung und Attacke, und diese Verhaltensweisen waren am häufigsten bei der Zellverproviantierung und dem Bau des Zellkragens zu sehen (Abb. 5). Mit zunehmendem Alter scheinen dominante Weibchen zunehmend aggressiver gegen SF-Weibchen zu werden. Außer solch agonistischem Verhalten gegen subordinate Weibchen, zeigten dominante auch Oophagie in Zellen, in denen erstere Eier abgelegt hatten.

Es ist wahrscheinlich, dass Oophagie in Verbindung mit agonistischen Interaktionen dazu dient, die Dominanz eines einzelnen Weibchens zu stärken, und dass diese Verhaltensweise möglicherweise eine Vorstufe zum Königinnenverhalten hochsozialer Bienen darstellen.

\footnotetext{
Euglossa / Verteilung des Reproduktionsvermögens / Oophagie / Sozialstruktur / Aufgabenverteilung
}

\section{REFERENCES}

Anerson L., Wcislo W.T. (2003) Dominantsubordinate relationship in a facultatively social, nocturnal bee, Megalopta genalis (Hymenoptera: Halictidae), J. Kans. Entomol. Soc. 76, 183-193.

Augusto S.C., Garófalo C.A. (2004) Nesting biology and social structure of Euglossa (Euglossa) townsendi Cockerell (Hymenoptera, Apidae, Euglossini), Insectes Soc. 51, 400-409.

Augusto S.C., Garófalo C.A. (2009) Bionomics and sociological aspects of Euglossa fimbriata (Apidae, Euglossini), Genet. Mol. Res. (Online) 8, 525-538.

Charnov, E.L. (1978) Evolution of eusocial behavior: offspring choice or parental parasitism? J. Theor. Biol. 75, 451-465.

Cocom Pech M.E., May-Itzá W.J., Medina Medina L.A., Quezada-Euán, J.G. (2008) Sociality in Euglossa (Euglossa) viridissima Friese (Hymenoptera, Apidae, Euglossini), Insectes Soc. 55, 428-433.

Dodson C.H. (1966) Ethology of some bees of the tribe Euglossini (Hymenoptera: Apidae), J. Kans. Entomol. Soc. 39, 607-629.

Dressler R.L. (1982) Biology of the orchid bees (Euglossini), Annu. Rev. Ecol. Syst. 13, 373-394.

Eberhard W.G. (1988) Group nesting in two species of Euglossa bees (Hymenoptera: Apidae), J. Kans. Entomol. Soc. 61, 406-411.

Eickwort G.C. (1986) First steps into Eusociality: The Sweat Bee Dialictus lineatus, Fla Entomol. 69, 742-754.

Garófalo C.A. (1985) Social structure of Euglossa cordata nests (Hymenoptera: Apidae: Euglossini), Entomol. Gen. 11, 77-83.

Garófalo C.A. (1987) Aspectos bionômicos e sociológicos de Euglossa cordata (Hymenoptera: Apidae: Euglossini), Tese de Livre-Docência, FFCL Ribeirão Preto - USP.

Garófalo C.A. (1992) Comportamento de nidificação e estrutura de ninhos de Euglossa cordata (Hymenoptera: Apidae: Euglossini), Rev. Bras. Biol. 52, 187-198.

Garófalo C.A., Camillo E., Augusto S.C., Jesus B.M.V., Serrano J.C. (1998) Nest structure and communal nesting in Euglossa (Glossura) annectans Dressler (Hymenoptera, Apidae, Euglossini), Rev. Bras. Zool. 15, 589-596.

Garófalo C.A., Camillo E., Serrano J.C., Rebêlo J.M.M. (1993) Utilization of trap nest by Euglossini species (Hymenoptera: Apidae), Rev. Bras. Biol. 53, 177-187.

Hogendoorn K., Velthuis H.H.W. (1999) Reproductive skew in mass provisioning carpenter bees in relation to age and size, Insectes Soc. 46, 198-207.

Johnstone R.A. (2000) Models of reproductive skew: a review and synthesis, Ethology 106, 5-26.

Kukuk P.F. (1992) Cannibalism in social bees, in: Elgar M.A., Crespi B.J. (Eds.), Cannibalism, 
ecology and evolution among diverse taxa, Oxford University Press, Oxford, pp. 214-237.

Kukuk P.F., Ward S.A., Jozwiak A. (1998) Mutualistic benefits generate an unequal distribution of risky activities among unrelated group members, Naturwissenschaften 85, 445-449.

Kumar S. (1975) Relations among bee size, cell size and caste in Lasioglossum zephyrum, J. Kans. Entomol. Soc. 48, 374-551.

Langer P., Hogendoorn K. , Keller L. (2004) Tug of war over reproduction in a social bee, Nature 428 , 844-847.

Langer P., Hogendoorn K., Schwarz M.P., Keller L. (2006) Reproductive skew in the Australian allodapine bee Exoneura robusta, Anim. Behav. 71, 193-201.

Martins G.F., Serrão J.E. (2004) A comparative study of the ovaries in some Brazilian bees (Hymenoptera; Apoidea), Pap. Avulsos Zool. (São Paulo) 44, 3, 45-53.

Michener C.D., Brothers D.J., Kamm D. (1971) Interactions in colonies of primitively social bees: Artificial colonies of Lasioglossum zephyrum, Proc. Natl. Acad. Sci. USA 68, 1241-1245.

Nemésio A. (2009) Orchid bees (Hymenoptera: Apidae) of the Brazilian Atlantic Forest, Zootaxa (Auckland) 2041, 242, 2009.

Otero J.T., Ulloa-Chacón P., Silverstone-Sopkin P., Giray T. (2008) Group nesting and individual variation in behavior and physiology in the orchid bee Euglossa nigropilosa Moure (Hymenoptera, Apidae), Insectes Soc. 55, 320-328.

Plateaux-Quénu C. (1992) Comparative biological data in two closely related eusocial species: Evylaeus calceatus (Scop.) and Evylaeus albipes (F.) (Hym., Halictinae), Insectes Soc. 39, 351-364.

Ramírez-Arriaga E., Cuadriello-Aguilar J.I., Hernández E.M. (1996) Nest structure and parasite of Euglossa atroveneta Dressler (Apidae: Bombinae: Euglossini) at Unión Juárez, Chiapas, México, J. Kans. Entomol. Soc. 69, 144-152.

Reeve H.K., Keller L. (1995) Partitioning of reproduction in mother-daughter versus sibling associations: a test of optimal skew theory, Am. Nat. 145, 119-132.

Reeve H.K., Keller L. (2001) Test of reproductiveskew models in social insects, Annu. Rev. Entomol. 46, 347-385.

Roberts R.B., Dodson C.H. (1967) Nesting biology of two communal bees, Euglossa imperialis e Euglossa ignita (Hymenoptera: Apidae) including description of larvae, Ann. Entomol. Soc. Am. 60, 1007-1014.

Sakagami S.F., Laroca S., Moure J.S. (1967) Two Brazilian apid nests worth recording in a reference to comparative bee sociology with descripition of Euglossa melanotricha Moure sp.n. (Hymenoptera: Apidae: Euglossini), Ann. Zool. Jap. 40, 45-50.

Santos M.L., Garófalo C.A. (1994) Nesting biology and nest re-use of Eulaema nigrita (Hymenoptera, Apidae, Euglossini), Insectes Soc. 41, 99-110.

Schwarz M.P., O’Keefe K.J. (1991) Order of eclosion and reproductive differentiation in a social allodapine bee, Ethol. Ecol. Evol. 3, 233-245.

Schwarz M.P., Woods R.E. (1994) Order of adult eclosion is a major determinant of reproductive dominance in the allodapine bee Exoneura bicolor, Anim. Behav. 47, 373-378.

Smith A.R., Wcislo, W. T., O’Donnel, S. (2008) Body size shapes caste expression, and cleptoparasitism reduces body size in the facultatively eusocial bees Megalopta (Hymenoptera: Halictidae), J. Insect Behav. 21, 394-406.

Soucy S.L., Giray T., Roubik D.W. (2003) Solitary and group nesting in the orchid bee Euglossa hyacinthina (Hymenoptera, Apidae), Insectes Soc. 50, 248-255.

Stubblefield J.W., Charnov, E.L. (1986) Some conceptual issues in the origin of eusociality, Heredity 57 , 181-187.

Tsuji K., Tsuji N. (2005) Why is dominance hierarchy age-related in social insects? The relative longevity hypothesis, Behav. Ecol. Sociobiol. 58, 517-526.

Wcislo W.T. (1997) Social interactions and behavioral context in a largely solitary bee, Lasioglossum (Dialictus) figueresis (Hymenoptera, Halictidae), Insectes Soc. 44, 199-208.

Yanega D. (1989) Caste determination and differential diapause whitin the first brood of Halictus rubicundus in New York (Hymenoptera: Halictidae), Behav. Ecol. Sociobiol. 24, 97-107.

Young A.M. (1985) Notes on the nest structure and emergence of Euglossa turbinifex Dressler (Hymenoptera; Apidae; Euglossini) in Costa Rica, J. Kans. Entomol. Soc. 58, 538-543.

Zimmermann Y., Roubik D.W., Quezada-Euan J.J.G., Paxton R.J., Eltz T. (2009) Single mating in orchid bees (Euglossa, Apinae): implications for mate choice and social evolution, Insectes Soc. 56, 241-249.

Zucchi R., Oliveira B.M., Camargo J.M.F. (1969a) Notas bionômicas sobre Euglossa (Glossura) intersecta Latreille 1838 e descrição de suas larvas e pupas (Euglossini, Apidae), Bol. Univ. Fed. Paraná, Zool. 3, 203-224.

Zucchi R., Sakagami S.F., Camargo J.M.F. (1969b) Biological observations on a tropical parasocial bee, Eulaema nigrita, with a review on the biology of Euglossinae (Hymenoptera, Apidae), A comparative study, J. Fac. Sci. Hokkaido Univ., Series IV, Zool 17, 271-380. 